\title{
PELATIHAN LAPORAN KEUANGAN SYARIAH BAGI ENTREPRENEUR MUDA DI MAKASSAR
}

\author{
Asbi Amin ${ }^{1)}$, Niken Probondani Astuti ${ }^{2)}$ \\ Program studi Akuntansi, Sekolah Tinggi Ilmu Ekonomi Makassar Bongaya \\ Email: asbi.amin@stiem-bongaya.ac.id ${ }^{1)}$,niken.probondani@stiem-bongaya.ac.id ${ }^{2)}$
}

\begin{abstract}
Abstrak
Pelatihan laporan keuangan syariah bagi entrepreneur muda di Makassar bertujuan untuk melatih para anak muda yang telah memiliki usaha dalam mempersiapkan dan selanjutnya membuat laporan keuangan syariah. Laporan keuangan syariah diperlukan untuk pengambilan keputusan bagi pemilik usaha sendiri dan pihak luar. Metode pelaksanaan dilakukan dengan cara mengadakan penyuluhan, pelatihan laporan keuangan syariah dan pendampingan. Adapun tujuan akhir dari pengabdan ini adalah entrepreneur muda mampu memahami dan melakukan pencatatan pada laporan keuangan syariah.
\end{abstract}

Kata Kunci: Laporan keuangan, syariah, Entrepreneur muda

\begin{abstract}
Training on sharia financial statements for young entrepreneurs in Makassar aims to train young people who already have business in preparing and subsequently making sharia financial reports. Islamic financial statements are needed for decision making for the business owners themselves and outside parties. The method of implementation is carried out by conducting counseling, training sharia financial reports and mentoring. The final goal of this service is for young entrepreneurs to be able to understand and take notes on Islamic financial statements.
\end{abstract}

Keywords: Sharia, financial statements, young entrepreneur

\section{PENDAHULUAN}

Beberapa tahun terakhir pertumbuhan pelaku Usaha Mikro Kecil Menengah (UMKM) terbilang cukup besar, khususnya yang didalangi oleh anak-anak muda. Mulai dari online shop, coffee shop hingga dunia kuliner. Pengusaha muda ini dengan cepat mendapatkan omzet yang besar, namun tanpa disadari banyak yang lalai dalam mengelola keuangan dengan baik. Banyak usaha yang berjalan luar biasa dalam bulan pertama, bulan kedua, dan seterusnya, namun pada akhirnya tutup. Salah satu permasalahannya adalah manajemen keuangan yang tidak tepat alias salah dalam mengelola keuangan. Maka dalam menjalankan sebuah usaha, selain marketing, keuangan juga menjadi poin penting agar tidak terjadi tutup usaha.
Data menunjukkan bahwa selama 5 Tahun terakhir jumlah entrepreneur di Indonesia mengalami peningkatan tetapi tidak signifikan, dimana pada tahun 2011 Jumlah entrepreneur di Indonesia mencapai $0.18 \%$ kemudian Pada Tahun 2013 naik menjadi $0.24 \%$ selanjutnya Pada Tahun 2016 naik menjadi $1.65 \%$, sehingga jumlah entrepreneur di Indonesia masih berada di bawah 2 $\%$, Sumber :GEM. Hal ini tentunya masih sangat jauh dengan negara-negara lain yang jumlah wirausahanya sudah di atas $2 \%$. Tahun 1998 juga membuktikan bahwa yang menyelamatkan negara Indonesia dari krisis ekonomi adalah dengan lahirnya UMKM / UKM dari berbagai sektor yang berada di seluruh Indonesia, itu artinya untuk meningkatkan pertumbuhan ekonomi nasional sangat diharapkan lahirnya banyak unit-unit usaha/bisnis sehingga masyarakat kita bisa sejahtera dan makmur (Trang, 2017). 
Laporan keuangan dalam dunia bisnis, menjadi hal yang pasti dimiliki oleh semua perusahaan. Baik itu perusahaan kecil seperti UKM ataupun perusahaan besar, baik yang sudah Go Public maupun yang belum. Penyusunan laporan keuangan harus menjadi bagian dari aktivitas wirausaha. Laporan ini digunakan untuk mengevaluasi, melakukan pengambilan keputusan, hingga sarana untuk mengembangkan usaha ke depan. Namun, aktivitas ini masih disalahkaprahkan oleh sebagian wirausaha.

Kurniawati et al (2012) menjelaskan bahwa penerapan akuntansi usaha kecil terutama usaha dagang masih sangat rendah karena kendala faktor pendidikan yang rendah termasuk dalam pengetahuan akuntansi dan kurangnya kesadaran akan pentingnya akuntansi. Sedangkan penelitian yang dilakukan oleh Wafirotin (2016) menyebutkan lebih dari 50\% UMKM mengalami kesulitan di sektor permodalan(Muda \& Kudus, 2018)

Dewasa ini, di sebagian besar negara di dunia, telah merespon positif perkembangan dan praktik-praktik ekonomi Islam, keuangan Islam, maupun akuntansi syariah. Telah banyak para ahli ekonomi syariah dari luar mengembangkan, meneliti, dan mengaplikansikannya.

Seiring dengan perkembangan bisnis yang berbasis syariah, menuntut pula perkembangan pencatatan atas akuntansi dan laporan keuangan syariah. Fenomena kegagalan akuntansi konvensional dalam memenuhi tuntutan masyarakat akan informasi keuangan yang benar, jujur dan adil, meningkatkan kesadaran di kalangan intelektual muslim akan perlunya pengetahuan akuntansi yang Islami.

Perumusan kembali kerangka konseptual pelaporan keuangan dengan mendasarkan pada prinsip kebenaran, kejujuran dan keadilan menjadi sangat mendesak untuk dilakukan. Mengingat akuntansi syariah sesuai dengan fitrah (kecenderungan) manusia yang menghendaki terwujudnya kehidupan bermasyarakat yang menjunjung tinggi etika dan tanggung jawab sosial.

Perbedaan antara paham akuntansi konvensional dengan akuntansi syariah. Paham akuntansi konvensional hanya mementingkan kaum pemilik modal (kapitalis), sedangkan akuntansi syariah bukan hanya mementingkan manusia saja, tetapi juga seluruh makhluk di alam semesta ini.

Jumlah pengusaha muda yang tersebar di seluruh daerah di Provinsi Sulawesi Selatan (Sulsel) saat ini sudah mencapai 630 orang. Mulai dari yang masih berskala kecil, menengah, maupun yang sudah mencapai usaha ekonomi skala besar. Di kota Makassar sendiri, persentase pertumbuhan jumlah pengusaha muda bisa mencapai 10 persen, sedangkan di beberapa daerah lain jumlahnya masih ada yang di bawah angka tersebut. Potensi pengusaha muda di Sulsel masih sangat besar, seiring dengan potensi ekonomi yang sangat besar yang tersedia di Sulsel, baik di sektor jasa, pertanian, perhotelan, dan sebagainya.

Kenyataan tersebut menjadi landasan bagi tim pengabdian masyarakat STIEM Bongaya untuk memberikan kontribusi terhadap entrepreneur muda. Dengan meningkatnya kompetensi keuangan UMKM wirausaha muda diharapkan dalam ruang lingkup mikro dapat meningkatkan bargaining position UMKM tersebut dan dalam ruang lingkup makro mampu mengembangkan perekonomian nasional. Sebagai bentuk dukungan terhadap UMKM di Indonesia yang tengah tumbuh perlu dilakukan pengabdian pelatihan laporan keuangan untuk meminimalisir kesalahan keuangan ataupun memberikan literasi keuangan kepada pengusaha muda.

\section{METODOLOGI PENGABDIAN}

\section{A. Khalayak Sasaran}

Khalayak sasaran yang dipilih adalah wirausaha (entrepreneur) muda di kota Makassar. Penetapan sasaran ini merupakan suatu upaya untuk meningkatkan pengetahuan dan keterampilan wirausaha muda menyusun laporan keuangan syariah.

\section{B. Metode Kegiatan}

Pelaksanaan kegiatan Pengabdian ini dilakukan dengan menggunakan metode ceramah, tutorial, dan diskusi. Adapun sistematika pelaksanaan kegiatan pengabdian ini adalah sebagai berikut:

Langkah 1 (Metode Ceramah) : Peserta diberikan motivasi agar memiliki kemauan untuk menggunakan akuntansi dalam kegiatan bisnisnya. Selain itu, peserta diberikan materi 
gambaran umum tentang akuntansi syariah dan peran penting akuntansi. Langkah pertama diselenggarakan selama 1 jam.

Langkah 2 (Metode Tutorial) : Peserta pelatihan diberikan materi akuntansi mulai dari pencatatan sampai dengan menyusun laporan keuangan. Langkah kedua diselenggarakan selama 5 jam.

Langkah 3 (Metode Diskusi) : Peserta pelatihan diberikan kesempatan untuk mendiskusikan permasalahan yang berkaitan dengan keuangan akuntansi syariah yang selama ini dihadapi. Langkah ketiga diselenggarakan selama 1 jam.

Jadwal kegiatan pengabdian dari penyusunan proposal sampai dengan tahap pelaporan hasil kegiatan pengabdian sebagai berikut:

a. Penyusunan proposal kegiatan dilakukan sebagai tahap pertama pengajuan program pengabdian masyarakat.

b. Persiapan pelatihan yang dilakukan meliputi pengumpulan materi-materi pelatihan.

c. Pelatihan yang akan dilakukan meliputi metode ceramah dan kegiatan tutorial.

d. Pendampingan

e. Pelaporan hasil kegiatan akan dilakukan sebagai bentuk pertanggungjawaban atas kegiatan.

Tabel 1. Pelaksanaan kegiatan

\begin{tabular}{|c|c|c|c|}
\hline $\mathrm{NO}$ & $\begin{array}{c}\text { HARI/ } \\
\text { TANGGAL }\end{array}$ & MATERI & WAKTU \\
\hline 1 & Rabu & $\begin{array}{l}\text { 1. Registrasi peserta } \\
\text { 2. Pengantar/Pendahuluan } \\
\text { Akuntansi } \\
\text { 3. Pengenalan Akuntansi } \\
\text { Syariah } \\
\text { 4. Ishoma } \\
\text { 5. PelaporanAkuntansi } \\
\text { Syariah }\end{array}$ & $\begin{array}{l}09.00-09.30 \\
09.30-10.30 \\
10.30-12.00 \\
12.00-13.00 \\
13.00-15.00\end{array}$ \\
\hline 2 & Kamis & $\begin{array}{l}\text { 1. Registrasi Peserta } \\
\text { 2. Praktik akuntansi syariah } \\
\text { 3. Ishoma } \\
\text { 4. Praktik akuntansi syariah }\end{array}$ & $\begin{array}{l}09.00-09.30 \\
09.30-10.30 \\
10.30-12.00 \\
13.00-15.00\end{array}$ \\
\hline 3 & $\begin{array}{c}\text { Tidak } \\
\text { terjadwal }\end{array}$ & $\begin{array}{l}\text { Pendampingan konsultasi } \\
\text { tentang akuntansi syariah }\end{array}$ & 7 jam \\
\hline
\end{tabular}

\section{PELAKSANAAN KEGIATAN}

Tahapan-tahapan kegiatan pengabdian diantaranya adalah sebagai berikut;

1) Tahapan kegiatan perencanaan pengabdian

2) Tahapan Kegiatan Pelaksanaan Pengabdian
Kegiatan dilaksanakan selama 2 hari. Kegiatan dilanjutkan dengan paparan materi oleh narasumber. Narasumber menyampaikan materi tentang pengantar akuntansi dan pengenalan akuntansi syariah. Narasumber menyampaikan beberapa pertanyaan awal untuk mengetahui pemahaman awal dari peserta. Beberapa peserta telah memahami akuntansi syariah, sementara yang lainnya masih belum begitu mengenal. Narasumber kemudian menyampaikan materi yang telah disiapkan, diantaranya mengenai pengantar akuntansi, pengenalan akuntansi syariah, pelaporan menggunakan akuntansi syariah. Kegiatan dilanjutkan dengan tanya jawab.

\section{PEMBAHASAN}

Di hari kedua kegiatan yang dilakukan adalah praktek akuntansi syariah dimana peserta diminta untuk mempraktekan materi yang sudah dipelajari di hari pertama. Peserta membuat pencatatan laporan arus kas, laporan laba rugi dan neraca sesuai dengan kaidah akuntansi syariah.

Sebelum kegiatan pengabdian berakhir, narasumber mengajukan pertanyaan kepada peserta untuk mengetahui pemahaman mengenai materi yang disampaikan. Pendampingan dalam pelatihan laporan keuangan syariah ini dilakukan selama 7 jam setelah pemberian materi selama 2 hari dilakukan.

Tahapan kegiatan evaluasi dilakukan dengan tujuan;

a) evaluasi proses pelaksanaan kegiatan pengabdian

b) evaluasi peningkatan pemahaman peserta mengenai pembuatan laporan keuangan syariah.

Evaluasi proses kegiatan pengabdian telah dilakukan dengan melihat jumlah peserta yang hadir, keseriusan peserta dalam mengikuti kegiatan, dan dukungan dari pihak STIEM Bongaya. Keseluruhan indikator menunjukkan bahwa kegiatan pengabdian ini dapat dilaksanakan dengan sukses dan lancar.

Peningkatan akuntansi syariah khususnya UMKM, sudah harus lebih diintensifkan dengan metode yang lebih sistematis dan terstruktur sehingga kedepan mampu meningkatkan persentase inklusi keuangan syariah. Kegiatan berikutnya akan 
dilaksanakan pelatihan yang lebih teknis yang diramu dalam bentuk pelatihan kelas.

\section{PENUTUP}

\section{Kesimpulan}

1. Potensi UMKM yang dikelola oleh entrepreneur muda sangat besar baik dari segi jumlah maupun kapasitasnya, sehingga patut untuk mendapat perhatian dalam rangka meningkatkan pemberdayaan dan kemitraan antarUMKM.

2. Kompetensi keuangan UMKM entrepreneur muda dilihat dari aspek permodalan, penjualan, laba usaha dan kemampuan menyusun laporan keuangan syariah masih sangat terbatas sehingga memerlukan upaya peningkatan kompetensi keuangan.

\section{Saran}

1. UMKM perlu mendapat pelatihan membangun jiwa wirausaha, membuat rencana bisnis dan analisa laporan keuangan, menggunakan aplikasi keuangan untuk mempermudah membuat pembukuan keuangan, serta mengetahui ekonomi syariah dan pembiayaan perbankan syariah.

2. Diperlukannya program berkelanjutan dalam mengenal akuntansi berbasis syariah dan praktek pembuatan laporan keuangan syariah.

\section{DAFTAR PUSTAKA}

Himawati, S \& Subono A (1979) Praktik Akuntansi dan Perkembangan Akuntansi Syariah di Indonesia, 1-12

Trang, Irvan (2017), Ibm tentang Pelatihan dan Pengembangan Menjadi Entrepreneur Berbasis Teknologi Informasi pada Mitra Usaha Laundry, ISSN : 2356-3966 Jurnal Manajemen Bisnis dan Inovasi Vol.4 No.2 